\title{
Optimized Temperature in Phosphorous Diffusion Gettering Setup of Chromium Transition Metal in Solar Grade Multicrystalline p-Type Silicon Wafer
}

\author{
D. Bouhafs*, N. Khelifati and Y. Kouhlane \\ CRTSE, Division de Développement de Dispositifs de Conversion à Semiconducteurs, \\ 2 Bvd Frantz Fanon, BP 140 Alger 7-Merveilles 16038, Algeria
}

\begin{abstract}
We have investigated in this work the effect of the temperature profile during homogeneous phosphorous diffusion gettering (PDG) on multicrystalline (mc-Si) silicon p-type wafers destined for photovoltaic solar cells. Temperatures were varied from $800^{\circ} \mathrm{C}$ to $950{ }^{\circ} \mathrm{C}$ with time cycle of 90 minutes. Phosphorous profile of $\mathrm{n}^{+} \mathrm{p}$ junction was measured by secondary ion mass spectroscopy (SIMS) from $0.45 \mu \mathrm{m}$ to $2.4 \mu \mathrm{m}$. Chromium concentration profile measured on the same samples by SIMS shows a high accumulated concentration of $\mathrm{Cr}$ atoms in the gettering layer at $900^{\circ} \mathrm{C}$ and $950^{\circ} \mathrm{C}$, compared to samples obtained at $800^{\circ} \mathrm{C}$ and $850^{\circ} \mathrm{C}$. The effective lifetime $\left(\tau_{\text {eff }}\right)$ of minority charge carriers characterized by quasi-steady state photoconductance (QSSPC) is in correlation with these results. From the QSSPC measurements we have observed an amelioration of $\tau_{\text {eff from }} 7 \mu$ s before PDG to $26 \mu \mathrm{s}$ in the samples after $\mathrm{PDG}$, processed at $900{ }^{\circ} \mathrm{C}$. This indicates the extraction of a non-negligible concentration $\left(5 \times 10^{14} \mathrm{~cm}^{-3}\right.$ to $\left.5 \times 10^{15} \mathrm{~cm}^{-3}\right)$ of $\mathrm{Cr}$ from the bulk to the surface gettering layer, as observed in the chromium SIMS profiles. A light degradation of $\tau_{\text {eff }}(18 \mu \mathrm{s})$ is observed in the samples treated at $950{ }^{\circ} \mathrm{C}$ due probably to a partial dissolution of the metallic precipitates, especially at the grain boundaries and in the dislocations vicinity. The related $\tau_{\text {Cr-Impurity }}$ lifetime value of about $8.5 \mu \mathrm{s}$ is extracted, which is the result of interstitial $\mathrm{Cr}_{\mathrm{i}} \mathrm{or} \mathrm{Cr}_{\mathrm{i}} \mathrm{B}_{\mathrm{s}}$ pairs, proving their strongest recombination activity in silicon.
\end{abstract}

DOI: 10.12693/APhysPolA.129.690

PACS/topics: 88.40.jj, 81.05.Bx, 81.65.Tx, 87.15.Pc

\section{Introduction}

Photovoltaic (PV) devices based on silicon $(\mathrm{Si})$ are the most common solar cells currently being produced, and it is mainly due to silicon technology that the PV has grown by $40 \%$ per year over the last decade [1]. Gettering of transition metal elements and passivation procedures have been studied for many years and are used effectively to increase the efficiency of multicristalline silicon (mc-Si) which represents more than $55 \%$ of the $\mathrm{Si}$ PV modules production in the world annually due to the ingoting and wafering process cost, compared with the Czochralski (CZ) monocristalline Si wafers. Unfortunately, this material is characterized by a relatively high density of defects like dislocations, grain-boundaries and the presence of high amount of transition metal elements which act as recombination centers, reducing electrical charge carrier lifetime $[2,3]$. The source of this high concentration of transition metal elements in the PV silicon wafers is due to the lower purity of the solar grade (SOG) feedstock used during the ingot growth cycle, as shown in Fig. 1 [2]. The main recombination activity sources in mc-Si wafers come from chromium $(\mathrm{Cr})$ and iron $(\mathrm{Fe})$. Several studies demonstrate that they create interstitial recombination centers and associate with the substitutional boron atoms to create pairs like $\mathrm{Fe}_{\mathrm{i}} \mathrm{B}_{\mathrm{s}}$, and $\mathrm{Cr}_{\mathrm{i}} \mathrm{B}_{\mathrm{s}}$,

*corresponding author; e-mail: bouhafsdjoudi@crtse.dz

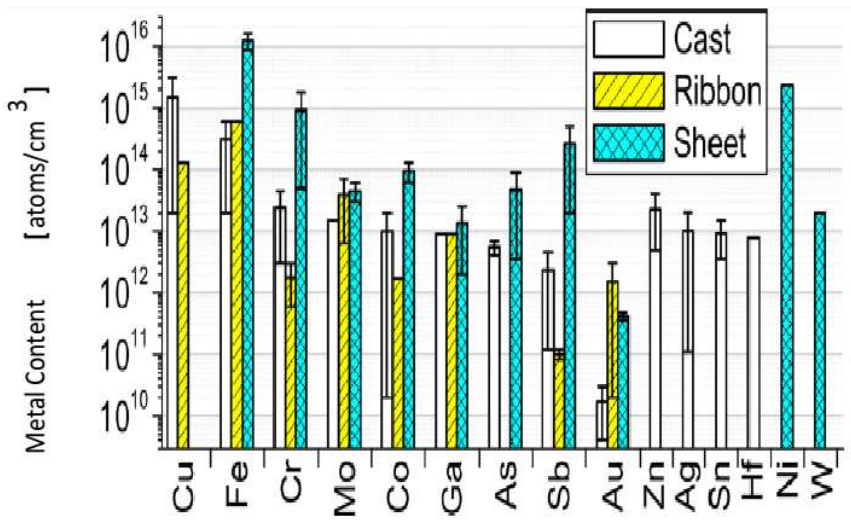

Fig. 1. Metal content in solar-grade silicon multicristalline ingot determined by NAA [2].

which act as acceptors and in some cases as donors depending on the energy position in the gap [4-8]. Table I illustrates the nature of recombination center of $\mathrm{Fe}$ and $\mathrm{Cr}$ in silicon and the relative capture cross-sections $\left(\sigma_{n}, \sigma_{p}\right)$ in function of their position (interstitial or substitutional) and composition.

To avoid the effect of the transition metallic elements on the carrier lifetime in mc-Si wafer we concentrated on the optimization of the phosphorous diffusion gettering process in a determined range of time and temperature profile. The negative effect of transition metal elements is well known. Cr is detrimental to silicon-based devices, 
TABLE I

Energy levels and capture cross-sections for Fe and Cr-related recombination centers in silicon.

\begin{tabular}{c|c|c|c}
\hline \hline $\begin{array}{c}\text { Recombination } \\
\text { center }\end{array}$ & $\begin{array}{c}\text { Energy } \\
\text { level }[\mathrm{eV}]\end{array}$ & $\begin{array}{c}\sigma_{n} \\
{\left[\mathrm{~cm}^{-2}\right]}\end{array}$ & $\begin{array}{c}\sigma_{p} \\
{\left[\mathrm{~cm}^{-2}\right]}\end{array}$ \\
\hline $\mathrm{Fe}_{\mathrm{i}}$ & $E_{\mathrm{V}}+0.38$ & $5 \times 10^{-14}$ & $7 \times 10^{-17}$ \\
$\mathrm{Fe}_{\mathrm{i}} \mathrm{B}_{\mathrm{s}}$ acceptors & $E_{\mathrm{C}}-0.23$ & $3 \times 10^{-14}$ & $2 \times 10^{-15}$ \\
$\mathrm{Cr}_{\mathrm{i}}$ & $E_{\mathrm{C}-0.22}$ & $2.3 \times 10^{-13}$ & $1.1 \times 10^{-13}$ \\
$\mathrm{Cr}_{\mathrm{i}} \mathrm{B}_{\mathrm{s}}$ & $E_{V}+0.27$ & $1.4 \times 10^{-13}$ & $1 \times 10^{-14}$
\end{tabular}

because it strongly reduces the carrier lifetime of crystalline silicon wafer at a relatively high concentration of about $5 \times 10^{14} \mathrm{~cm}^{-3}$, as measured by SIMS in an earlier study [9].

\section{Experiment}

In our experiment mc-Si boron doped p-type wafers with resistivity of (1-3) $\Omega \mathrm{cm}$ were used. All wafers originated from the same briquette and were adjacent. Firstly, the surface was chemically cleaned in $\mathrm{NaOH}: \mathrm{H}_{2} \mathrm{O}$ bath to remove the saw damage defects, followed by a neutralization step in $\mathrm{HCl}: \mathrm{H}_{2} \mathrm{O}$ for a few minutes to reduce the presence of $\mathrm{Na}$ atoms which act as electrical activation centers. Four batches of few wafers underwent a homogeneous phosphorous gettering process in a pressure controlled atmosphere with different temperatures in the range of 800 to $950{ }^{\circ} \mathrm{C}$ during 90 minutes. PDG setup was realized in a tube furnace using a phosphorus oxy-chloride $\left(\mathrm{POCL}_{3}\right)$ liquid as the diffusion source. The $\mathrm{n}^{+} \mathrm{p}$ junction and the chromium profiles relative to each gettering run were measured using secondary ion mass spectroscopy (SIMS) - IMS4FE7 from Cameca, which has a relatively lower detection limit of transition metals than that of the Neutron Atomic Activation (NAA) $\left(2 \times 10^{14} \mathrm{~cm}^{-3}\right.$ for $\left.\mathrm{Cr}\right)$. The effective lifetime $\tau_{\text {eff }}$ measurements were performed using the WCT-120 quasi-steady-state photoconductance technique (QSSPC) to evaluate the effectiveness of the gettering in the mc-Si wafers.

\section{Results and discussion}

In Fig. 2, the $\mathrm{n}^{+} \mathrm{p}$ junction SIMS profiles are illustrated in function of the temperature of the PDG setup. Surface concentration of phosphorous $N_{\mathrm{s}}$ is around $2 \times 10^{21} \mathrm{~cm}^{-3}$ for samples treated at $800^{\circ} \mathrm{C}$ and $850^{\circ} \mathrm{C}$ and drops to $2 \times 10^{20} \mathrm{~cm}^{-3}$ for those treated at 900 and $950^{\circ} \mathrm{C}$ due to temperature-enhanced diffusion of $\mathrm{P}$ atoms. The depth profile is $0.4,1.5,1.7$ and $2.5 \mu \mathrm{m}$ for samples treated at $800,850,900$ and $950^{\circ} \mathrm{C}$, respectively. From Fig. 2 we observe that a great amount of $\mathrm{P}$ atoms has quickly diffused into the bulk of the wafer via the crystallographic defects and grain boundaries bellow $0.5 \mu \mathrm{m}$ in comparison with $\mathrm{P}$ profiles obtained at 800 and $850^{\circ} \mathrm{C}$, which indicates that the gettering layer is more important for processes at temperatures bellow $850^{\circ} \mathrm{C}$.

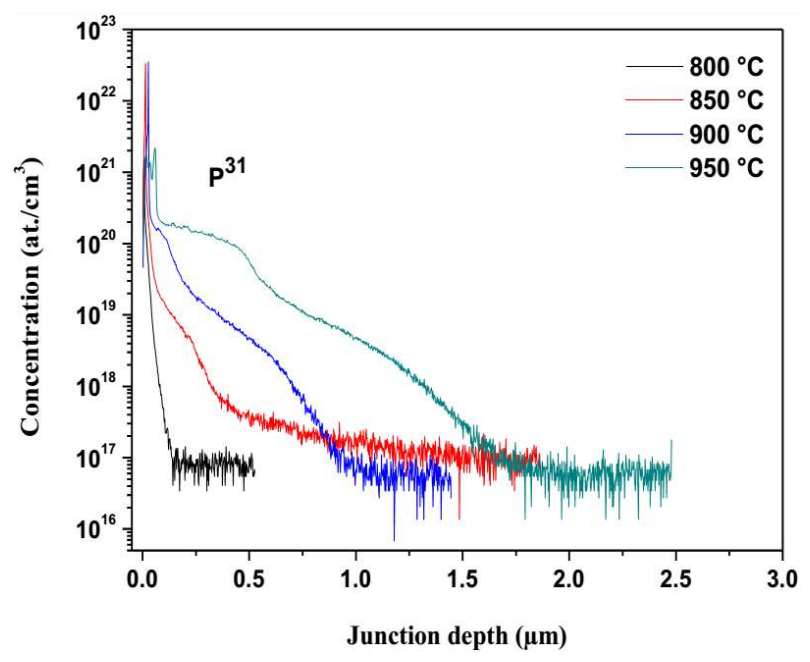

Fig. 2. SIMS spectra of phosphorous profile for different PDG processes.

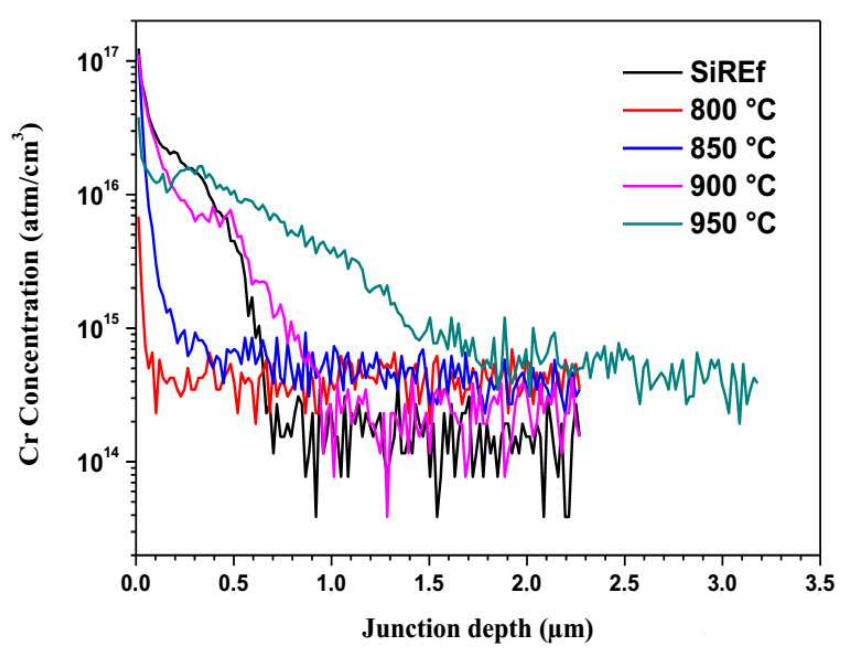

Fig. 3. Evolution of the SIMS profile of chromium in mc-Si with the temperature of PDG processes during $90 \mathrm{~min}$.

After chemical etching of the gettering layer (20 $\mu \mathrm{m}$ from each face), we have characterized the chromium profile for the reference mc-Si wafer and those after the PDG. We can see that a high concentration of $\mathrm{Cr}$ atoms has diffused to the silicon surface at $900^{\circ} \mathrm{C}$ and $950^{\circ} \mathrm{C}$, regarding their content in the reference sample, as shown in Fig. 3. A part of $\mathrm{Cr}$ atoms at relatively high temperature originate from a partial dissolution of precipitates of this metallic element in the vicinity of the crystallographic defects, grain-boundaries. On other hand, the $\mathrm{Cr}$ concentration at 800 and $850{ }^{\circ} \mathrm{C}$ is lower than that measured in Si-Ref, as a result of low migration of this metallic element to the surface of the treated silicon wafers.

Because the QSSPC technique is very sensitive to surface passivation, before each $\tau_{\text {eff }}$ measurement, the wafers were chemically cleaned in a piranha etch sequence: HF $10 \%+\mathrm{H}_{2} \mathrm{SO}_{4}: \mathrm{H}_{2} \mathrm{O}_{2}$ at $80{ }^{\circ} \mathrm{C}$ for $15 \mathrm{~min}+\mathrm{HF} 10 \%$ 
to etch the chemically grown $\mathrm{SiO}_{2}$ layer. The values of $\tau_{\text {eff }}$ are determined at excess carrier density $n=$ $1 \times 10^{15} \mathrm{~cm}^{-3}$ to avoid the effect of the traps in the low injection region. Figure 4 illustrates the effective lifetime measured on mc-Si wafers before and after PDG gettering process. The best amelioration of $\tau_{\text {eff }}=26 \mu \mathrm{s}$ is obtained with PDG run at $900{ }^{\circ} \mathrm{C}$. Remember that the initial values of minority carrier lifetime was around $7 \mu \mathrm{s}$. With the PDG runs at $800^{\circ} \mathrm{C}$ and $850{ }^{\circ} \mathrm{C}$ the lifetime is lightly affected by the gettering process with values of 10 and $11 \mu \mathrm{s}$, which indicates a low level of migration of the transition metallic elements from the bulk to the surface. Nevertheless, at $950^{\circ} \mathrm{C}$, degradation of $\tau_{\text {eff }}$ is observed $(18 \mu \mathrm{s})$. This result is in correlation with the SIMS profile (Fig. 2). At this temperature stage, the dissolution of the $\mathrm{Cr}$ precipitates in the bulk probably takes place, leading to a high concentration of substitutional $\mathrm{Cr}$ atoms, acting as recombination centers.

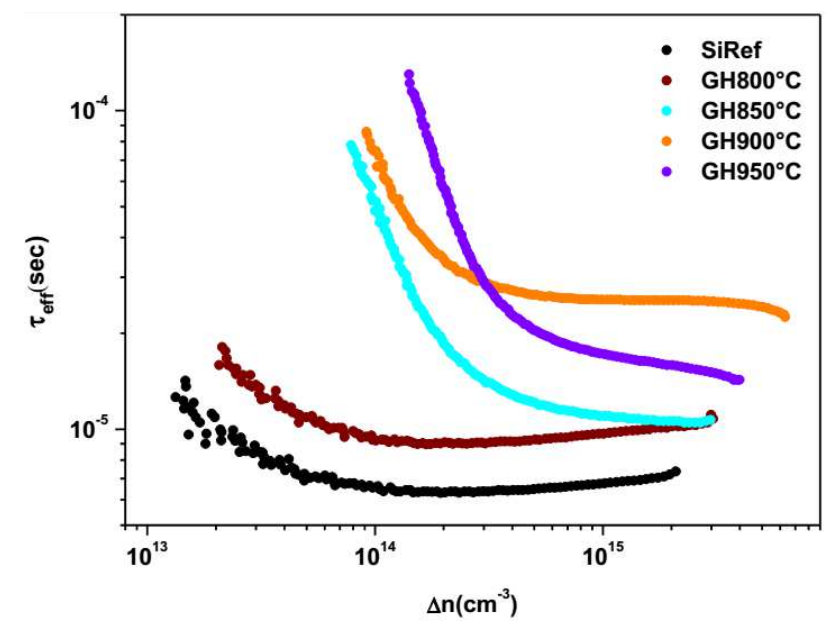

Fig. 4. Evolution of $\tau_{\text {eff }}$ in mc-Si wafers before and after phosphorous gettering process.

\section{Evaluation of effective lifetime with $\mathrm{Cr}$ related centers}

In the non gettered mc-Si wafer, the bulk lifetime $\tau_{\text {non getter }}$ can be expressed as:

$$
\frac{1}{\tau_{\text {non-gett }}}=\frac{1}{\tau_{\text {impurity }}}+\frac{1}{\tau_{\text {gett }}},
$$

where $\tau_{\text {gett }}$ corresponds to carrier lifetime after impurity gettering and the $\tau_{\text {non-gett }}$ represents the minority carrier lifetime before gettering (Reference Si wafer). By measuring $\tau_{\text {eff }}$ as a function of injection level by QSSPC for both, non gettered mc-Si wafers and the gettered ones we can evaluate the bulk lifetime level related to $\mathrm{Cr}$ impurity concentration.

$$
\frac{1}{\tau_{\text {impurity }}}=\frac{1}{\tau_{\text {non-gett }}}-\frac{1}{\tau_{\text {gett }}} .
$$

Using this model, the carrier lifetime related to the chromium impurity was determined and the results are illustrated in Fig. 5.

From the QSSPC lifetime measurements illustrated in Fig. 5, carried out on the mc-Si wafer before and after

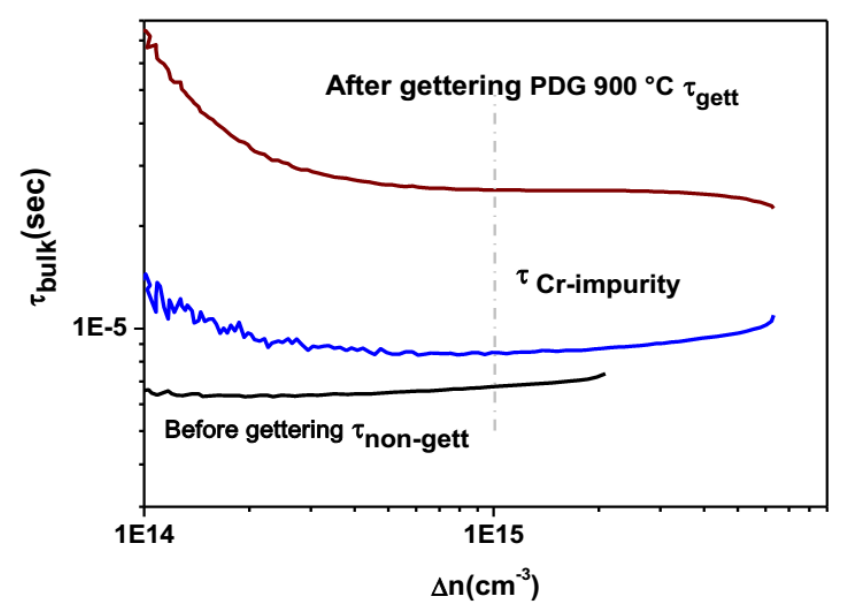

Fig. 5. QSSPC lifetime versus excess carrier density for a mc-Si wafer before and after PDG run with the lifetime related to $\mathrm{Cr}$ impurities.

gettering at $900^{\circ} \mathrm{C}$ we can deduce that the minority carrier lifetime of the $\mathrm{Cr}$ impurity is lower than $\tau_{\text {gett }},(26 \mu \mathrm{s})$. In fact, this $\tau_{\text {impurity }}$ includes gettering of other elements witch also act as recombination centers, such as Fe, Mn and $\mathrm{Cu}$. Regarding the SIMS curves in Fig. 3, the extraction of a non-negligible concentration $\left(5 \times 10^{14} \mathrm{~cm}^{-3}\right.$ to $5 \times 10^{15} \mathrm{~cm}^{-3}$ ) of $\mathrm{Cr}_{\mathrm{i}}$ from the bulk to the surface of the gettering layer, dominates the $\tau_{\text {gett }}$ component. The QSSPC measured $\tau_{\text {Cr-Impurity value of about } 8.5 \mu \mathrm{s}}$ is a result of interstitial $\mathrm{Cr}_{\mathrm{i}}$ or $\mathrm{Cr}_{\mathrm{i}} \mathrm{B}_{\mathrm{s}}$ pairs, proving their recombination activity, leading to the reduction of the carrier lifetime. Both defects are amongst the strongest known recombination centers in silicon as reported by Schmidt et al. [4].

\section{Conclusions}

Homogeneous phosphorus diffusion gettering (PDG) on p-type multicristalline silicon (mc-Si) was realized in the temperature range from $800^{\circ} \mathrm{C}$ to $950{ }^{\circ} \mathrm{C}$ during $90 \mathrm{~min}$. Phosphorous and chromium SIMS profiles suggest that a part of impurity atoms at a relatively higher temperature $\left(950^{\circ} \mathrm{C}\right)$ is driven from a partial dissolution of chromium precipitates in the vicinity of the crystallographic defects, grain-boundaries and from the oxygen precipitates which are generally decorated by metallic impurities. On other hand, the Cr concentration at 800 and $850^{\circ} \mathrm{C}$ is lower than that measured in Si-Ref, due to low migration to the surface of the treated silicon wafers. QSSPC-measured values of $\tau_{\text {eff }}$ at excess carrier density $n=1 \times 10^{15} \mathrm{~cm}^{-3}$ before and after PDG gettering process show an amelioration with a maximum of about $26 \mu$ s obtained in PDG run at $900{ }^{\circ} \mathrm{C}$. In addition, we have determined $\tau_{\text {gett }}$ which corresponds to the carrier lifetime after $\mathrm{Cr}$ impurity gettering and we have observed that it is lower than $\tau_{\text {eff }}=26 \mu$ s resulting from the total QSSPC lifetime. These results prove that the strongest recombination activity of chromium in the studied silicon wafers stems from interstitial chromium defects $\mathrm{Cr}_{\mathrm{i}}$ and $\mathrm{Cr}_{\mathrm{i}} \mathrm{B}_{\mathrm{s}}$. 


\section{Acknowledgments}

This work is realized at DDCS-Division/CRTSE and financed by the National Fund for Research of Algeria DGRSD/MESRS.

\section{References}

[1] S. Binetti, M. Acciarri, A. Le Donne, M. Morgano, Y. Jestin, Int. J. Photoen. 2013, ID 249502 (2013).

[2] T. Buonassisi, A.A. Istratov, M.D. Pickett, M. Heuer, J.P. Kalejs, G. Hahn, M.A. Marcus, B. Lai, Z. Cai, S.M. Heald, T.F. Ciszek, R.F. Clark, D.W. Cunningham, A.M. Gabor, R. Jonczyk, S. Narayanan, E. Sauar, E.R. Weber, Prog. Photovolt. 14, 513 (2006).
[3] S.A. McHugo, H. Hieslmair, E.R. Weber, Appl. Phys. A 64, 127 (1997).

[4] J. Schmidt, R. Krain, K. Bothe, G. Pensl, S. Beljakowa, J. Appl. Phys. 102, 123701 (2007).

[5] D.H. Macdonald, Ph.D. Thesis, Australian National University, 2001

[6] A.A. Istratov, H. Hieslmair, E.R. Weber, Appl. Phys. A 69, 13 (1999).

[7] H. Conzelmann, K. Graff, E.R. Weber, Appl. Phys. A 30, 169 (1983).

[8] K. Mishra, Appl. Phys. Lett. 68, 3281 (1996).

[9] N. Khelifati, D. Bouhafs, M. Boumaour, S.E.H. Abaidia, B. Palahouane, Mater. Sci. Semicond. Proc. 15, 56 (2012). 